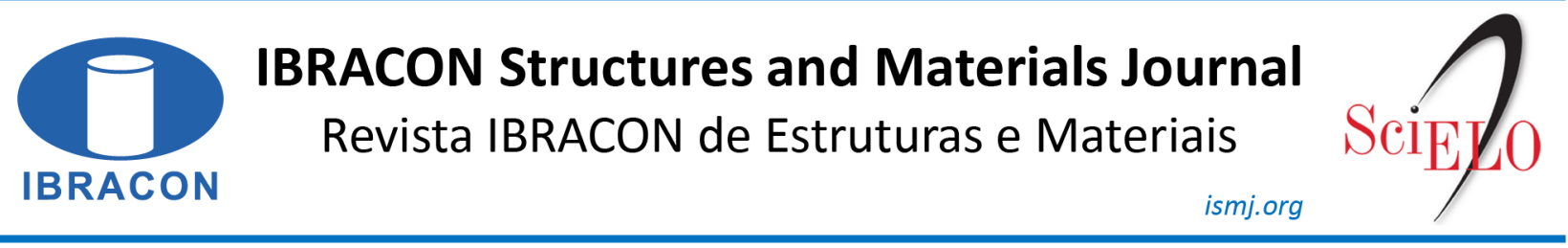

ORIGINAL ARTICLE

\title{
Compression resistance of repaired structural concrete elements after core extraction
}

\section{Resistência à compressão de elementos estruturais de concreto reparados após extração de testemunhos}

\author{
Tauana Bartikoski ${ }^{\mathrm{a}}$ \\ Vanessa Oerle Kautzmann ${ }^{\mathrm{a}}$ \\ Vinicius de Kayser Ortolan ${ }^{\mathrm{a}}$ \\ Bernardo Fonseca Tutikian ${ }^{\mathrm{b}}$ (10) \\ Regina Modolo ${ }^{\mathrm{b}}$
}

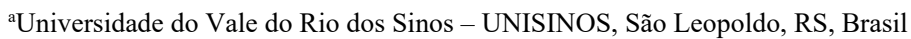 \\ bUniversidade do Vale do Rio dos Sinos - UNISINOS, Programa de Pós-graduação em Engenharia Civil - PPGEC, São Leopoldo, RS, Brasil
}

Received 10 September 2019

Accepted 11 February 2020

\begin{abstract}
Core sampling for testing is considered a reliable method to provide information on structural materials and is one of the most implemented techniques in the evaluation of concrete elements. However, core drilling results in a decrease in cross section that can compromise structural mechanical strength even if the extracted section is repaired. Norm NBR 7680-1 recommends dry pack as a repair method but also allows the use of other techniques as long as its effectiveness is proven. This work evaluated the resistance of repaired structural prototypes after core drilling sampling. Concrete blocks with $20 \mathrm{MPa}$ resistance were produced from which cores of $100 \mathrm{~mm}, 75 \mathrm{~mm}$ and $50 \mathrm{~mm}$ in diameter were extracted. The blocks were repaired with $20 \mathrm{MPa}$ concrete, grout and dry pack techniques. The reconstitution with concrete showed poorest performance, while dry pack led to strengths even higher when compared to reference values.
\end{abstract}

Keywords: core sampling, dry pack, grout, compression strength.

Resumo: A extração de testemunhos para ensaios é considerada um método confiável no fornecimento de dados do material que compõe uma estrutura, sendo um dos mais utilizados na avaliação de elementos de concreto. Porém, a retirada de volume de material representa a diminuição da seção transversal, podendo comprometer a resistência mecânica da estrutura, mesmo com recomposição da seção.Apesar de indicar o dry pack como técnica de preenchimento, a NBR 7680-1 permite o uso de outros meios de reconstituição, desde que comprovada sua eficácia. Este artigo avaliou a resistência à compressão de protótipos estruturais submetidos à extração de testemunhos reconstituídos. Foram preparados blocos de concreto C20 dos quais extraiu-se testemunhos nos diâmetros de 100,75 e $50 \mathrm{~mm}$. Os blocos foram preenchidos com concreto $\mathrm{C} 20$, graute e dry pack. O reparo com concreto demonstrou o pior desempenho, enquanto o dry pack resultou em resistências superiores aos blocos de referência.

Palavras-chave: extração de testemunhos, dry pack, graute, resistência à compressão.

How to cite: T. Bartikoski, V. O. Kautzmann, V. K. Ortolan, B. F. Tutikian, and R. Modolo, "Compression resistance of repaired structural concrete elements after core extraction," IBRACON Struct. Mater. J., vol. 13, no. 4, e13413, 2020, https://doi.org/10.1590/S198341952020000400013

\section{INTRODUCTION}

On-site evaluation methods are used to evaluate the compression resistance of reinforced concrete. This is necessary due to uncertainties in the properties of concrete or to better assess the loading capacity of the structural element [1]-[3]. Among in situ methods, core extraction is considered the most reliable since it replicates closely the real properties of the material [4]-[7]. Core 
extraction results are considered superior to mold casting since core samples are subjected to the same environmental and load conditions as the source material during curing and aging [8].

Core extraction is recognized as a semi-destructive technique [9], [10] since part of the volume of the structure is lost in sampling and small fissures may appear from the extraction process. This may result in a decrease in mechanical strength of the structure and compromise either performance or safety. In order to prevent these, the missing section of the element must be reconstituted with material capable of, at least, restoration to its initial condition [11], [12].

There are several reference works indicating techniques and materials for repairing concrete and specific norms which recommend suitable techniques for a variety of situations [13]-[16]. In Brazil, norm ABNT NBR 7680-1:2015 [17] recommends different techniques depending on the sample extracted. Compacted mortar with a dry consistency, commonly known as dry pack, is recommended for reconstitution of holes drilled horizontally, as in pillars and beams. Structural grout or pourable concrete is recommended for holes drilled vertically, as in slabs. However, ABNT NBR 7680-1:2015 allows the use of other techniques and materials as long as their efficiency is proven. In specific cases, besides grout and dry pack, concrete itself may be used as a repair material [18]-[23]

Compatibility between the original structure and repair material is another important aspect in reconstitution. To this end, several properties are considered relevant but Morgan [18] denotes the modulus of elasticity and volumetric variance of the repair material. In the case of using concrete itself as the repair material, special attention must be given to the filling process since adhesiveness between new and old concrete might be hard to achieve and the use of additional bonding agents might be necessary [24], [25]. This concern is not limited only to concrete as a repair material. Several works stress the need to promote adhesiveness to the drilled structure regardless of the repair material, be it through bonding agents or mechanical methods [19], [20], [26]-[30]

The use of grout is advantageous because it reaches elevated resistances early on and is a material with a high degree of fluidity, compactness and uniformity. Because of its fluidity, grout usually requires molds [31]-[33]. On the other hand, there is a resistance to adhesiveness since fluid materials are more affected by shearing motions between the concrete surface and repairing material [34].

The use of dry pack is more suitable for situations in which molding is not possible since it lacks fluidity. Dry pack can be used for repairs in either horizontal or vertical directions and is less susceptible to shrinkage due to its low water/cement ratio. This also results in less fissures and more of adhesiveness to the drilled structure [28], [33]. This technique is also recommended to fill deep cavities with limited accessibility [35].

Concrete itself can also be used as a repair material in situations in which a large volume must be filled back in. Compared to grout or plaster, it is a more economical alternative and tends to have thermal dilation properties similar to the structure to be repaired while also allowing a more uniform finish [26], [28].

Core sample dimensions are relevant to testing, especially with regards to diameter-to-height ratio. Some studies have noted that there is no difference in compression resistance values with regards to the dimensions of core samples [36]-[39]. However, other studies report that samples with smaller diameters present lower compression resistance values [40], [41]. Overall, a recommended height-to-diameter ratio of 2 was considered necessary to avoid the use of correction factors in the results [17], [36]-[39], [42], [43].

Core sample extraction has the potential to create micro-fissures in concrete. This not only reduces the mechanical resistance of the material but also can induce lower resistance in samples with smaller diameters since they have a higher surface-to-volume ratio [36], [44]. The minimum sample diameter recommended by ASTM is of $100 \mathrm{~mm}$ [16] while British Standards EN 12504 allows compression testing on samples as small as $50 \mathrm{~mm}$ in diameter without the need for correction factors [45]. Norm ABNT NBR 7680:2015 recommends a minimum diameter of $100 \mathrm{~mm}$ for core samples but allows diameters of $75 \mathrm{~mm}$ and $50 \mathrm{~mm}$ in specific situations [17]. Another factor to be considered is the concrete class which causes further effects in compression tests of samples of varying diameter. The volume of the sample may or may not be important depending on the mechanical resistance of the concrete. Concretes with higher resistance are less likely to develop fissures during the extraction process when compared to concretes with lower resistance. Higher resistance concretes also present a more robust transition zone with higher adhesiveness surface with less flaking [44].

The objective of this study is to further contribute to the analysis of different repair methods in finished structures from which core samples have been extracted. In particular, structural grout and dry pack techniques were analyzed and compared. Also, since there were divergences with respect to the effect of sample diameters, comparative mechanical tests were conducted on blocks with different repair sizes. 


\section{METHODOLOGY}

\subsection{Materials}

A total of 24 concrete blocks of class $\mathrm{C} 20$ were produced in a batch plant and divided in 3 groups, each containing 8 blocks. Group 1 contained clocks measuring $500 \mathrm{~mm} \times 300 \mathrm{~mm} \times 230 \mathrm{~mm}$, group 2 contained clocks measuring $375 \mathrm{~mm} \times 225 \mathrm{~mm} \times 180 \mathrm{~mm}$ and group 3 contained clocks measuring $250 \mathrm{~mm} \times 250 \mathrm{~mm} \times 150 \mathrm{~mm}$. Concrete dosing followed the methodologies of Tutikian and Helene [46] and Gil et al. [47]. This procedure was adopted so the extracted core samples had a constant volume ratio with respect to the original concrete blocks.

Following core extraction, three different recovery methods were used. The fist method made use of concrete with the same characteristics as the original block. The concrete mixture was prepared in a vertical axis mixer. The second method utilized industrial-grade structural grout made from Portland cement, quartz sand and special additives. Grout was prepared with a water/solid material ratio of 0.12 and aging compression tests measured a resistance of $42 \mathrm{MPa}$ after 7 days and $50 \mathrm{MPa}$ after 28 days. The third method utilized dry pack made from a thixotropic and single component industrial plaster specific for structural repairs. Preparation used a water/solid material ratio of 0.13 and aging compression tests measured a resistance of $30 \mathrm{MPa}$ after 7 days and $40 \mathrm{MPa}$ after 28 days. Coarse basalt aggregate with a maximum granulometry of $9.5 \mathrm{~mm}$ was incorporated between layers as proposed by norm ABNT NBR 7680-1, Anex A [17].

\subsection{Curing of concrete blocks}

Concrete blocks were demolded and conditioned in a climate-controlled chamber kept at $23 \pm 2{ }^{\circ} \mathrm{C}$ and relative air humidity of $97 \%$ for 28 days. Following this period, core samples were extracted.

\subsubsection{Core sample extraction}

Cylindrical core samples were extracted from the cured blocks. Procedures followed ABNT NBR 7680-1 [17] recommendations with a height/diameter ratio $(\mathrm{h} / \mathrm{d})$ of 2 . Three distinct sample diameters were chosen: $\varnothing 100 \mathrm{~mm}$, $\varnothing 75 \mathrm{~mm}$ e $\varnothing 50 \mathrm{~mm}$ with the last 2 reserved for concrete blocks with higher reinforcement.

Table 1 displays the characteristics of the concrete, source concrete block dimensions, sample dimensions, number of samples extracted, \% volume of the sample relative to the block and the type of material used in the repair. From the blocks measuring $500 \mathrm{~mm} \times 300 \mathrm{~mm} \times 230 \mathrm{~mm}$ and $375 \mathrm{~mm} \times 225 \mathrm{~mm} \times 180 \mathrm{~mm}, 2$ samples with diameters of $100 \mathrm{~mm}$ and $75 \mathrm{~mm}$ were extracted, respectively. From the blocks measuring $250 \mathrm{~mm} \times 250 \mathrm{~mm} \times 150 \mathrm{~mm}, 4$ samples $50 \mathrm{~mm}$ in diameter were extracted. The position of each hole of extraction kept at distance of at least one sample-diameter from each other, and one sample-diameter with respect to the edges of the block as seen in Figure 1. Two blocks from each dimension were kept intact as reference. The drilled blocks had samples extracted horizontally in a direction perpendicular to the pouring of concrete. The drill was diamond-crowned and water-cooled.
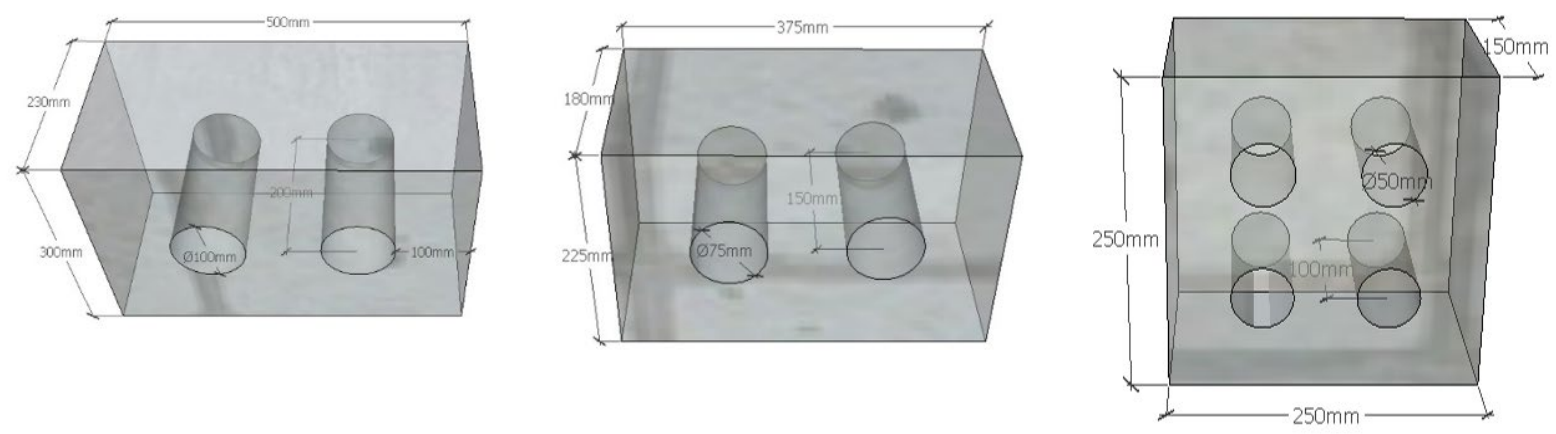

Figure 1 - Drilling hole placement according to block dimension 
Table 1 - Concrete block and core sample identifications

\begin{tabular}{|c|c|c|c|c|c|c|c|c|}
\hline \multirow{2}{*}{$\begin{array}{c}\text { Block } \\
\text { Resistance } \\
\text { Class }\end{array}$} & \multicolumn{3}{|c|}{ Block Dimensions } & \multicolumn{2}{|c|}{ Sample Size } & \multirow{2}{*}{$\begin{array}{c}\text { Number of } \\
\text { Samples }\end{array}$} & \multirow{2}{*}{$\begin{array}{c}\text { \% Extracted } \\
\text { Volume }\end{array}$} & \multirow{2}{*}{ Type of Repair } \\
\hline & $\mathbf{L}(\mathbf{m m})$ & $\mathbf{H}(\mathbf{m m})$ & $\mathbf{W}(\mathbf{m m})$ & $\mathrm{D}(\mathbf{m m})$ & H (mm) & & & \\
\hline $\mathrm{C} 20$ & 500 & 300 & 230 & - & - & 0 & 0 & Reference \\
\hline $\mathrm{C} 20$ & 500 & 300 & 230 & - & - & 0 & 0 & Reference \\
\hline $\mathrm{C} 20$ & 500 & 300 & 230 & 100 & 200 & 2 & 9 & $\mathrm{C} 20$ \\
\hline $\mathrm{C} 20$ & 500 & 300 & 230 & 100 & 200 & 2 & 9 & $\mathrm{C} 20$ \\
\hline $\mathrm{C} 20$ & 500 & 300 & 230 & 100 & 200 & 2 & 9 & Grout \\
\hline $\mathrm{C} 20$ & 500 & 300 & 230 & 100 & 200 & 2 & 9 & Grout \\
\hline $\mathrm{C} 20$ & 500 & 300 & 230 & 100 & 200 & 2 & 9 & Dry Pack \\
\hline $\mathrm{C} 20$ & 500 & 300 & 230 & 100 & 200 & 2 & 9 & Dry Pack \\
\hline $\mathrm{C} 20$ & 375 & 225 & 180 & - & - & 0 & 0 & Reference \\
\hline $\mathrm{C} 20$ & 375 & 225 & 180 & - & - & 0 & 0 & Reference \\
\hline $\mathrm{C} 20$ & 375 & 225 & 180 & 75 & 150 & 2 & 9 & $\mathrm{C} 20$ \\
\hline $\mathrm{C} 20$ & 375 & 225 & 180 & 75 & 150 & 2 & 9 & $\mathrm{C} 20$ \\
\hline $\mathrm{C} 20$ & 375 & 225 & 180 & 75 & 150 & 2 & 9 & Grout \\
\hline $\mathrm{C} 20$ & 375 & 225 & 180 & 75 & 150 & 2 & 9 & Grout \\
\hline $\mathrm{C} 20$ & 375 & 225 & 180 & 75 & 150 & 2 & 9 & Dry Pack \\
\hline $\mathrm{C} 20$ & 375 & 225 & 180 & 75 & 150 & 2 & 9 & Dry Pack \\
\hline $\mathrm{C} 20$ & 250 & 250 & 150 & - & - & 0 & 0 & Reference \\
\hline $\mathrm{C} 20$ & 250 & 250 & 150 & - & - & 0 & 0 & Reference \\
\hline $\mathrm{C} 20$ & 250 & 250 & 150 & 50 & 100 & 4 & 8 & $\mathrm{C} 20$ \\
\hline $\mathrm{C} 20$ & 250 & 250 & 150 & 50 & 100 & 4 & 8 & $\mathrm{C} 20$ \\
\hline $\mathrm{C} 20$ & 250 & 250 & 150 & 50 & 100 & 4 & 8 & Grout \\
\hline $\mathrm{C} 20$ & 250 & 250 & 150 & 50 & 100 & 4 & 8 & Grout \\
\hline $\mathrm{C} 20$ & 250 & 250 & 150 & 50 & 100 & 4 & 8 & Dry Pack \\
\hline $\mathrm{C} 20$ & 250 & 250 & 150 & 50 & 100 & 4 & 8 & Dry Pack \\
\hline
\end{tabular}

\subsubsection{Block repair}

Block repair was conducted utilizing C20 concrete, grout and dry pack. Each block was prepared according to NBR 7680-1 [17], with the internal surface of each hole cleaned and saturated with moisture. This procedure was realized in order to ensure a better adhesiveness between the concrete block and the repair material [34], [48], [49]. Concrete repair was conducted by inserting fresh C20 material in molds and extruding it into the hole. After hardening, excess concrete was shaved off. Grout repair followed the same procedure as concrete as seen in Figure 2 . Dry pack repair was conducted according to NBR 7680-1, Annex A [17]. The drilled hole was filled with alternating layers of mortar of thickness of less than $5 \mathrm{~cm}$ and coarse gravel of thickness between $9.5 \mathrm{~mm}$ and $25 \mathrm{~mm}$. A cylindrical pestle $25 \mathrm{~mm}$ in diameter was used to push in and compact each layer as seen in Figure 3. Once filled, the external surface of the repair was smoothed out with a metallic trowel and curing allowed to happen. Figure 4 shows the finished repaired blocks with concrete, grout and dry pack.

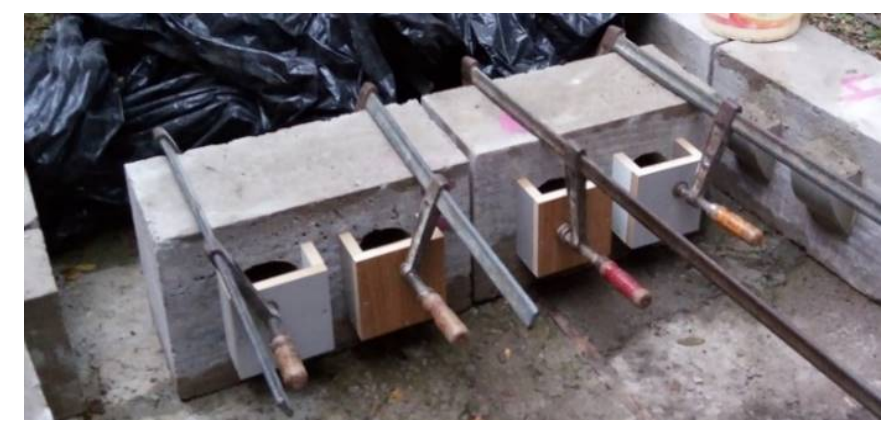

Figure 2 - Molds for concrete and grout repair 

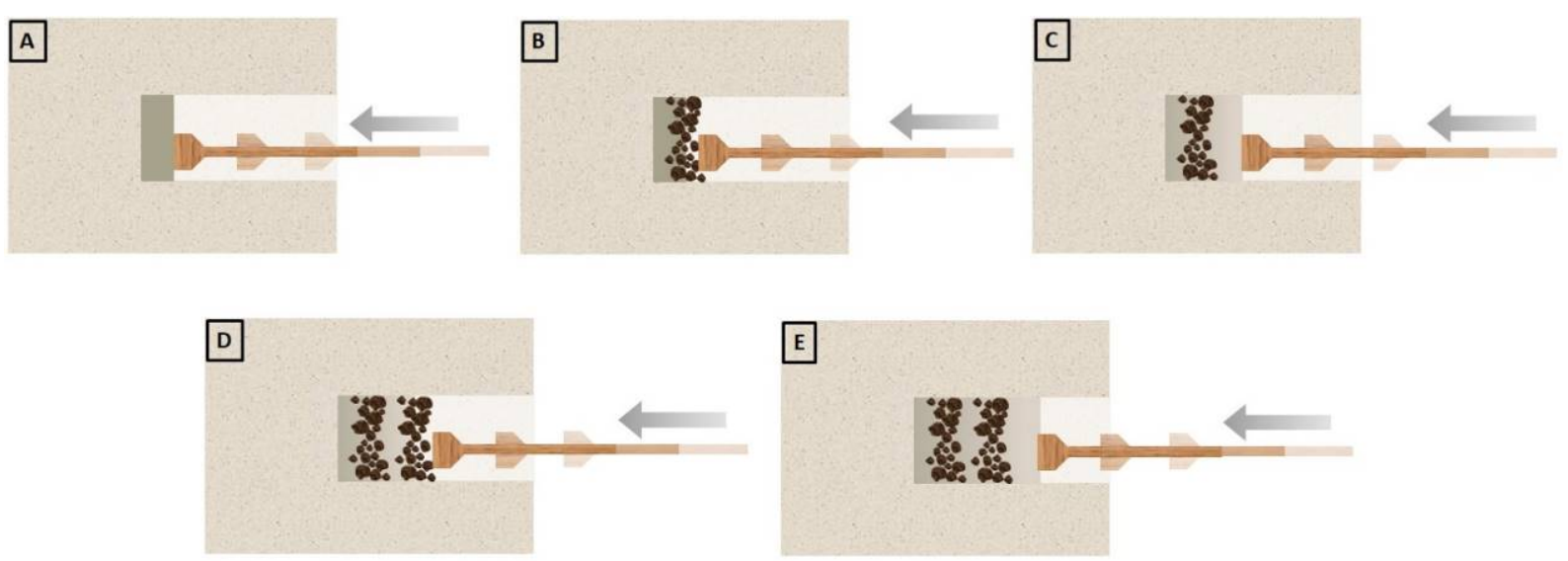

Figure 3 - Dry pack filling procedure

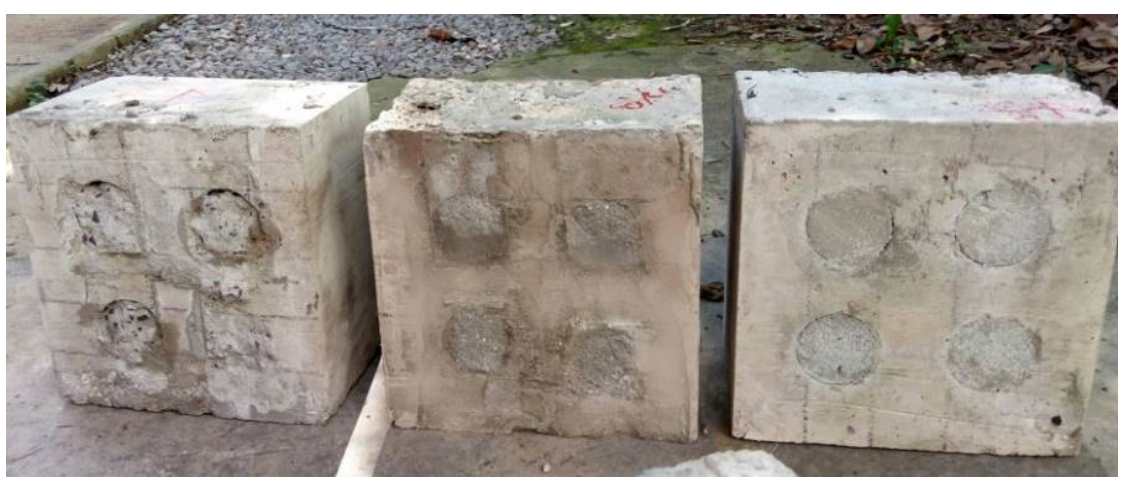

Figure 4 - Finalized repaired blocks with concrete, grout and dry pack (left to right)

\subsubsection{Curing of repair material and testing}

Repair material applied to the blocks was cured for 7 days with water spraying. After curing, the repaired block was allowed to age for a total of 28 days from the date of reconstitution. Compressions tests were performed in a universal press and neoprene slabs were used to distribute the load along the contact surface as seen in Figure 5.

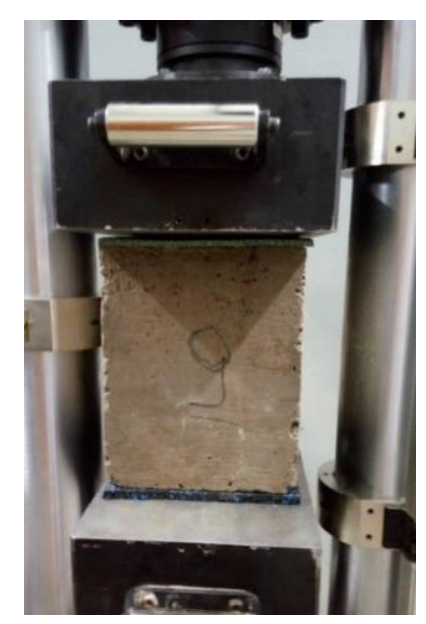

Figure 5 - Compression test in universal press 


\section{RESULTS AND DISCUSSION}

Results are presented in Table 2 and Table 3. Table 2 displays the compression resistance of cylinders measuring $\varnothing 10 \mathrm{~cm} \times 20 \mathrm{~cm}$ of $\mathrm{C} 20$ and grout after 28 days of aging. Table 3 displays the compression resistance of the concrete blocks with respect to each repair material and core sample size. The potential tension values are in accordance with norm ABNT NBR 12655:2015 [50]. Table 3 shows that, of the repaired concrete blocks, the ones with dry pack repair had the best performance. In particular, the repair with $100 \mathrm{~mm}$ diameter had a compression resistance $8.2 \%$ higher than the reference blocks.

Table 2 Repair material compression resistance

\begin{tabular}{cccc}
\hline Type of material & Load (kN) & Tension (MPa) & Average Tension (MPa) \\
\cline { 2 - 3 } C20 & 303.41 & 38.6 & 39.1 \\
\cline { 2 - 4 } Graute & 310.31 & 39.5 & 62.0 \\
\cline { 2 - 4 } & 540.64 & 68.9 & 55.0 \\
\hline
\end{tabular}

Table 3 Concrete Block Compression Resistances

\begin{tabular}{|c|c|c|c|c|c|c|c|c|c|}
\hline Material & $\varnothing(\mathrm{mm})$ & $\begin{array}{c}\text { Tension } \\
\text { (MPa) }\end{array}$ & $\begin{array}{c}\text { Potential } \\
\text { Tension } \\
\text { (MPa) }\end{array}$ & $\varnothing(\mathrm{mm}$ & $\begin{array}{l}\text { Tension } \\
\text { (MPa) }\end{array}$ & $\begin{array}{c}\text { Potential } \\
\text { Tension } \\
\text { (MPa) }\end{array}$ & $\varnothing(\mathrm{mm}$ & $\begin{array}{c}\text { Tension } \\
\text { (MPa) }\end{array}$ & $\begin{array}{c}\text { Potential } \\
\text { Tension } \\
\text { (MPa) }\end{array}$ \\
\hline Reference & - & $\begin{array}{c}11.0 \\
8.3\end{array}$ & 11.0 & - & $\begin{array}{l}10.1 \\
13.5\end{array}$ & 13.5 & - & $\begin{array}{c}9.5 \\
12.1\end{array}$ & 12.1 \\
\hline $\mathrm{C} 20$ & & $\begin{array}{l}8.0 \\
8.4\end{array}$ & 8.4 & & $\begin{array}{l}10.0 \\
10.6\end{array}$ & 10.6 & & $\begin{array}{l}7.5 \\
6.5\end{array}$ & 7.5 \\
\hline Grout & 100 & $\begin{array}{l}10.1 \\
11.1\end{array}$ & 11.1 & 75 & $\begin{array}{l}7.2 \\
8.1\end{array}$ & 8.1 & 50 & $\begin{array}{l}6.6 \\
7.3\end{array}$ & 7.3 \\
\hline Dry pack & & $\begin{array}{c}8.6 \\
11.9\end{array}$ & 11.9 & & $\begin{array}{c}9.6 \\
12.9\end{array}$ & 12.9 & & $\begin{array}{l}9.1 \\
9.1\end{array}$ & 9.1 \\
\hline
\end{tabular}

Comparisons of the performance of the repaired blocks and reference blocks are shown in Figure 6. Blocks with $100 \mathrm{~mm}$ diameter extractions repaired with grout and dry pack were able to resist compression levels higher than the reference blocks. As extraction size decreased, repaired blocks underperformed with respect to reference blocks. The worst performance was obtained with the $75 \mathrm{~mm}$ diameter extraction block repaired with grout: a $40 \%$ reduction with respect to the reference block.

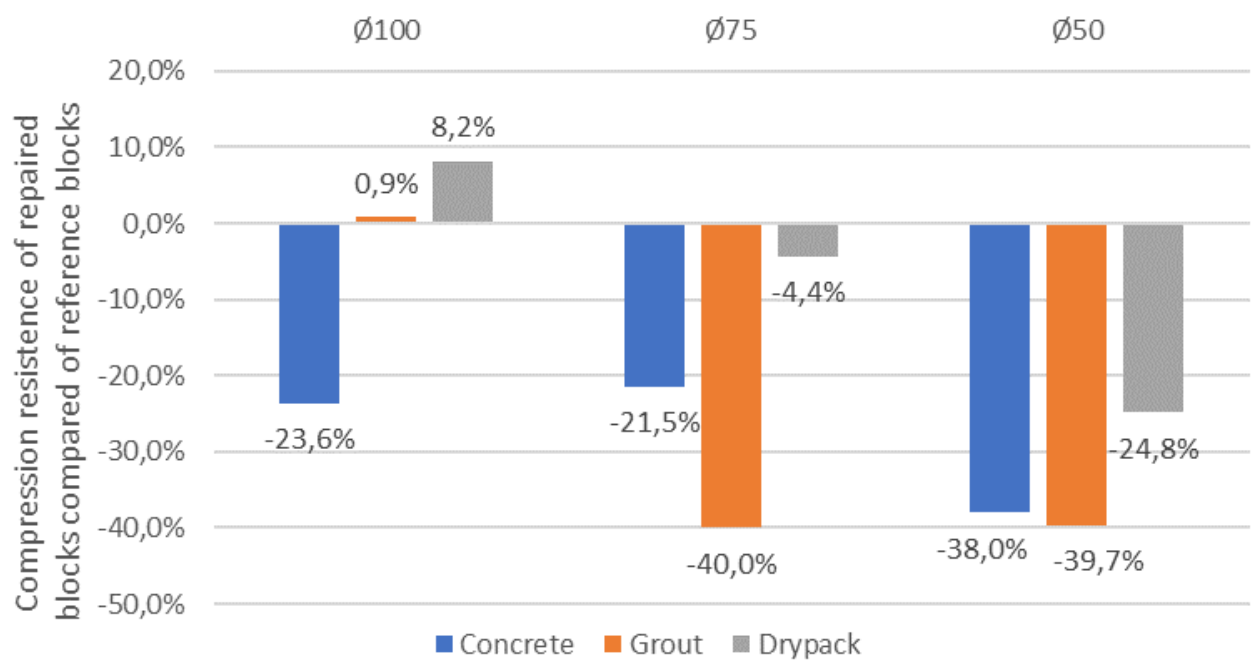

Figure 6 - Compression resistance of repaired blocks compared to reference blocks 
Figure 7 shows the effect of diameter of the extracted region on the compression resistance of each repair material. Overall, it can be stated that a $50 \mathrm{~mm}$ diameter extraction compromised the mechanical resistance of the repaired block the most regardless of the repair material. This was likely a result of damage to the concrete block in the extraction of this smallest sample. If the concrete itself was less resistant, core extraction could lead to the appearance of micro-fractures and flaking of aggregates. In this case, a core sample with a higher area/volume ratio became a relevant factor in the loss of mechanical properties.
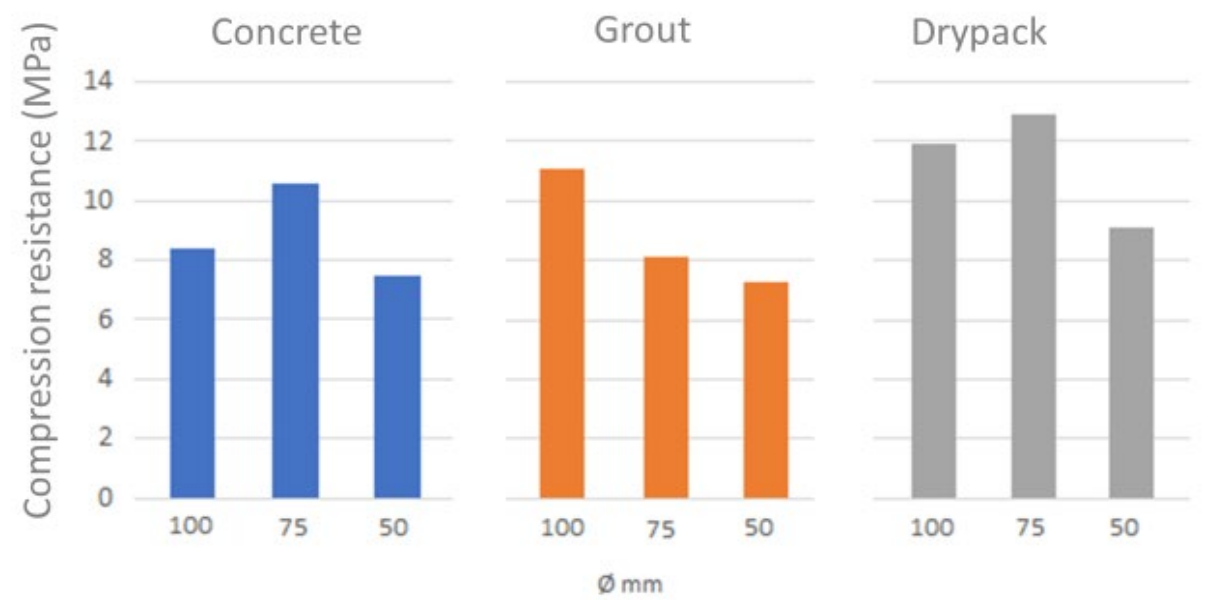

Figure 7 - Relative effect of diameter in repair material

Overall, dry pack presented the best efficiency in recovering the mechanical properties of the repaired blocks. This might be related to the water/cement ratio in this type of material. Smaller water content in the mixture leads to less shrinkage which is highly important in the structural repair of concrete. A shrinking repair material might leave gaps between the original material and filled volume so that the block would tend to fracture under compression before it can incorporate the resistance of the repair material. This phenomenon can be observed in the fracture characteristics of each block in Figure 8, with the fracture occurring in the interface between the repaired core and the block. While this may explain dry pack performance, comparison of the water/solid ratio between dry pack and grout showed minimal differences insufficient to cause such difference in performance ( 0.13 for dry pack and 0.12 for grout). In this case, compaction effects associated with the filling technique were likely to have influenced the results. In the case of grout, repair material was poured in with no special compaction executed. Dry pack, in the other hand, was filled in several packed layers and the energy of compaction could have induced greater adhesiveness and left fewer gaps in the interface with the block.
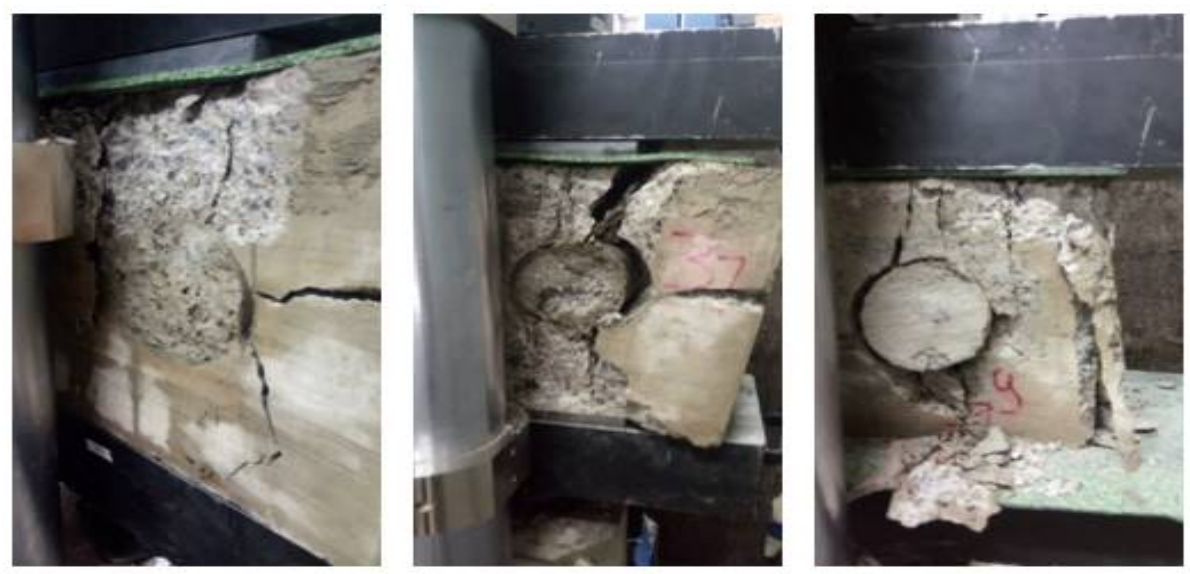

Figure 8 - Fracture characteristics of each repaired block (left to right: C20, grout and dry pack) 


\section{CONCLUSIONS}

Results of this study demonstrated that dry pack was the most efficient filling material to repair core sample extraction volumes in concrete elements. Concrete itself was shown to be an inefficient repair material with the repaired block having a $38 \%$ reduction in compression resistance. Water content in the repair material might be considered an important factor in the performance of repaired blocks.

The diameter of core samples also influenced the results. Large core diameters resulted in repaired blocks that could exceed reference results. In the other hand small core diameters, which contain a higher surface/volume ratio, performed poorly probably due to damages to the concrete block structure caused during extraction.

\section{REFERÊNCIAS}

[1] A. Neville, "Core tests: easy to perform, not easy to interpret," Concr. Int., vol. 23, no. 11, pp. 59-68, 2001.

[2] A. F. Domínguez and J. J. H. Albear, "Relación entre laresistencia a compresión de testigos y probetas de hormigón: estado del arte y propuestas para actualización de la normativa cubana," in Ann. $11^{a}$ Conf. Cient. Téc. Construc., Havana, 2016.

[3] A. R. Grubbs, A. C. Carroll, A. K. Schindler, and R. W. Barnes, Evaluation of In-place Concrete Strength by Core Testing (Research Report 2). Alabama: Alabama Depart. Transp., Nov. 2016, ALDOT Project 930-828.

[4] American Concrete Institute, Guide for Obtaining Cores and Interpreting Compressive Strength Results, 214.4R-100, 2010.

[5] A. Masi and M. Vona, "Prove distruttive e non distruttive su materialie delementi strutturali di edificie sistenti in cemento armato," in Conv. $12^{\circ}$ Nazio. AIPnD,” Potenza, 2007.

[6] M. Tuncan, O. Arioz, K. Ramyar, and B. Karasu, "Assessing concrete strength by means of small diameter cores," Constr. Build. Mater., vol. 22, no. 5, pp. 981-988, 2008, http://dx.doi.org/10.1016/j.conbuildmat.2006.11.020.

[7] A. S. F. D. S. Martins and H. M. Maia Fo., "Verificação da resistência do concreto in loco: métodos de ensaios mais usuais," Vetor, vol. 25, no. 2, pp. 25-40, 2015.

[8] H. J. N. Lima, R. L. Silva, J. M. Silva, and G. S. S. A. Melo, "Avaliação da resistência à compressão do concreto: comparativo entre corpo de provas de moldados e testemunhos extraídos," InterScientia, vol. 6, no. 2, pp. 2-11, 2018, http://dx.doi.org/10.26843/interscientia.v6i2.881.

[9] M. H. C. Sahuinco, “Utilização de métodos não destrutivos e semi-destrutivos na avaliação de pontes de concreto,” Ph.D. dissertation, Esc. Politéc., Univ. São Paulo, São Paulo, SP, 2011.

[10] B. Kasal, M. Drdacky, and I. Jirovski, "Semi-destructive methods for evaluation of timber structures," Trans. Built Environ., vol. 66, no. 8, 2003.

[11] J. L. R. Ortiz and J. M. B. Díaz, "Evaluación de laresistencia de pilares de hormigón por medio de testigos cortados: nuevasaportaciones," Rev. Ing. Constr., vol. 28, no. 276, pp. 57-69, 1975.

[12] M. Vona and D. Nigro, "Evaluation of the predictive ability of the in situ concrete strength through core drilling and its effects on the capacity of the RC columns," Mater. Struct., vol. 48, no. 4, pp. 1043-1059, 2015, http://dx.doi.org/10.1617/s11527-013-0214-2.

[13] American Concrete Institute, Guide to Concrete Repair, 546-14, 2014.

[14] International Organization for Standardization, Testing of Concrete - Part 4: Strength of Hardened Concrete, ISO 1920-4, 2005.

[15] American Society for Testing and Materials, Standard Specification for Packaged, Dry, Rapid-Hardening Cementitious Materials for Concrete Repairs, ASTM C928/C928M-13, 2013.

[16] American Society for Testing and Materials, Standard Specification for Packaged Dry, Hydraulic-Cement Grout (Nonshrink), ASTM C1107/C1107M-17, 2017.

[17] Associação Brasileira de Normas Técnicas. Concreto: Extração, Preparo, Ensaio e Análise de Testemunhos de Estruturas de Concreto - Parte 1: Resistência à Compressão Axial, ABNT NBR 7680-1, 2015.

[18] D. R. Morgan, "Compatibility of concrete repair materials and systems," Constr. Build. Mater., vol. 10, no. 1, pp. 57-67, 1996, http://dx.doi.org/10.1016/0950-0618(95)00060-7.

[19] S. C. Fagury and J. B. L. Liborios, "A utilização de concretos e pastas, com adição de sílica ativa e aditivo superplastificante, como material de reparo para estruturas de concreto," in An. Cong. Bras. Eng. Ciên. Mat., Natal, 2002.

[20] F. L. Gondim, "Estudo da interface entre o concreto e o material de reparo mediante microscopia," M.S. thesis, Univ. Fed. Uberlândia, Uberlândia, MG, 2005.

[21] L. Tula, P. S. F. Oliveira, and P. Helene, “Grautes para reparo," in VII Cong. Lat. Ame. Patol. Constr., Madrid, 2003, pp.139-152.

[22] P. D. Krauss and D. J. Naus, "Repair materials and techniques for concrete structures in nuclear power plants," Nucl. Eng. Des., vol. 181, no. 1-3, pp. 71-89, 1998, http://dx.doi.org/10.1016/S0029-5493(97)00336-1.

[23] J. H. Paul, "Repair, renovation and strengthening of concrete structures," in Eval. Rehabil. Concr. Struct.: Proc. ACI Int. Conf., Mexico City, Sept. 2002.

[24] M. Z. B. Jumaat, M. H. Kabir, and M. Obaydullah, "Structural performance of reinforced concrete beams repairing from spalling," Eur. J. Sci. Res., vol. 45, no. 1, pp. 89-102, 2010. 
[25] J. S. C. Astorqui, "Patología de lasestructuras de hormigón,” in Manual de Patología de Laedificación, V. Rodríguez, Ed., Madri: Univ. Politéc. Madri, 2004, chap. 1, pp. 6-84.

[26] M. Marcelli, Sinistros na Construção Civil: Causas e Soluções Para Danos e Prejuizos em Obras, 1st ed. São Paulo: PINI, 2007.

[27] J. Nakamura, "Reparo, reforço e recuperação de concreto," Rev. Techne, vol. 146, 2009.

[28] B. M. B. Albergaria, "Inspeção e reabilitação de estruturas de betão armado,” M.S. thesis, Inst. Sup. Eng. Porto, Porto, 2013.

[29] F. Pacheco, R. Christ, A. M. Gil, and B. F. Tutikian, "Aplicação de MEV e microtomografia 3D na investigação da distribuição de fibras em compósitos cimentícios avançados," Rev. IBRACON Estrut. Mater., vol. 9, no. 6, pp. 824-841, Dec 2016.

[30] J. J. O. Andrade and B. F. Tutikian, "Resistência mecânica do concreto," in Concreto: Ciência e Tecnologia, G. C. Isaia, Ed., São Paulo: IBRACON, 2011, chap. 17, pp. 615-651.

[31] E. A. Silva, “Técnicas de recuperação e reforço de estruturas de concreto armado,” Undergraduate thesis, Univ. Anhembi Morumbi, 2006.

[32] M. V. Z. Stotz, "Métodos de recuperação de estruturas de concreto armado deterioradas pela corrosão nas armaduras," Rev. Especialize, vol. 10, no. 10, pp. 1-14, 2015.

[33] L. R. Fernandes, "Metodologias para produção de pré-fabricados em concreto armado e protendido com abordagem das manifestações patológicas que surgem na fabricação e montagem," Undergraduate thesis, Esc. Eng., Univ. Fed. Minas Gerais, Belo Horizonte, MG, 2015.

[34] H. Beushausen, B. Höhlig, and M. Talotti, "The influence of substrate moisture preparation on bond strength of concrete overlays and the microstructure of the OTZ," Cement Concr. Res., vol. 92, pp. 84-91, 2017, http://dx.doi.org/10.1016/j.cemconres.2016.11.017.

[35] M. D. Graeser and M. C. Jensen, "South channel dam rehabilitation project-successfully addressing dam rehabilitation challenges," in Proc. 6th IAHR International Symposium on Hydraulic Structures, Portland, 2016.

[36] J. O. Vieira Fo., "Avaliação da resistência à compressão do concreto através de testemunhos extraídos: contribuição à estimativa do coeficiente de correção devido aos efeitos broqueamento,” Ph.D. dissertation, Esc. Politéc., Univ. São Paulo, São Paulo, SP, 2007.

[37] E. Castro, "Estudo da resistência à compressão do concreto por meio de testemunhos de pequeno diâmetro e esclerometria," Master thesis, Prog. Pós-grad. Eng. Civ., Univ. Fed. Uberlândia, Uberlândia, MG, 2009.

[38] J. M. A. Almeida, B. V. Silva, and J. M. Désir, "Resistência à compressão simples de concretos através da extração de testemunhos com pequenas dimensões," in An. $56^{\circ}$ Cong. Bras. Concr., Natal, 2014.

[39] L. C. P. Silva Fo. and P. Helene, "Análise de estruturas de concreto com problemas de resistência e fissuração," in Concreto: Ciência e Tecnologia, G. C. Isaia, Ed., São Paulo: IBRACON, 2011. chap. 32, pp. 1129-1174.

[40] F. M. Bartlett and J. G. MacGregor, "Effect of core diameter on concrete core strengths," Mater. J., vol. 91, no. 5, pp. 460-470, 1994.

[41] M. H. F. Medeiros and A. P. B. Capraro, "Resistência a compressão em testemunho de concreto: influência do fator de esbeltez, diâmetro da amostra e método de extração," Rev. Eletronica Eng. Civ. Goias, vol. 13, no. 1, pp. 240-250, 2017.

[42] American Association of State Highway and Transportation Officials, Obtaining and Testing Drilled Cores and Sawed Beams of Concrete, T24, 2009.

[43] P. C. Bilesk and C. E. S. Tango, "Avaliação do concreto de peças estruturais pequenas pelo método dos cilindros montados," Rev. Tecnol. Constr., vol. 121, pp. 92-98, 2007.

[44] A. C. Carroll, A. R. Grubbs, A. K. Schindler, and R. W. Barnes, Effect of Core Geometry and Size on Concrete Compressive Strength (Research Report 1). Alabama: Alabama Depart. Transp., Jul. 2016, ALDOT Project 930-828.

[45] British Standards, Testing Concrete in Structures - Cored Specimens: Taking, Examining and Testing in Compression, BS EN 12504-1, 2009.

[46] B. F. Tutikian and P. Helene, "Dosagem dos concretos de cimento Portland," in Concreto: Ciência e Tecnologia, G. C. Isaia, Ed., São Paulo: IBRACON, 2011, 2v., chap. 12, pp. 415-451.

[47] A. M. Gil, K. H. Khayat, and B. F. Tutikian, "An experimental approach to design self-consolidating concrete," Constr. Build. Mater., vol. 229, no. 30, pp. 116939, 2019, http://dx.doi.org/10.1016/j.conbuildmat.2019.116939.

[48] J. S. Lapa, "Patologia, recuperação e reparo das estruturas de concreto," Undergraduate thesis, Esc. Eng., Univ. Fed. Minas Gerais, Belo Horizonte, 2008.

[49] I. De la Varga, J. F. Munoz, D. P. Bentz, R. P. Spragg, P. E. Stutzman, and B. A. Graybeal, "Grout-concrete interface bond performance: effect of interface moisture on the tensile bond strength and grout microstructure," Constr. Build. Mater., vol. 170, pp. 747-756, 2018, http://dx.doi.org/10.1016/j.conbuildmat.2018.03.076.

[50] Associação Brasileira de Normas Técnicas, Versão Corrigida: 2015 - Concreto de Cimento Portland - Preparo, Controle, Recebimento e Aceitação-Procedimento, ABNT NBR 12655:2015, 2015.

Author contributions: T. Bartikoskia: conceptualization, metodology, writing. V. O. Kautzmanna : conceptualization, formal analysis, writing. V. K. Ortolan ${ }^{\mathrm{a}}$ : conceptualization, formal analysis, writing. B. F. Tutikian ${ }^{\mathrm{b}}$ : formal analysis, writing, supervision. R. Modolo ${ }^{\mathrm{b}}$ : supervision.

Editors: Bernardo Horowitz, José Luiz Antunes de Oliveira e Sousa, Guilherme Aris Parsekian. 